\title{
O INSTITUTO AMERICANO DO STATE ACTION EM CONTRAPOSIÇÃO AO SISTEMA DA EFICÁCIA HORIZONTAL ADOTADO PELA CONSTITUIÇÃO BRASILEIRA
}

\author{
ODILON CASTELLO BORGES NETO*
}

\begin{abstract}
RESUMO: O presente estudo intenta esclarecer a doutrina do state action, sistema de proteção de direitos fundamentais utilizado nos Estados Unidos da América, seus limites e suas implicações, e, em linhas gerais, analisar como ele se distingue do sistema da eficácia horizontal adotado pela Constituição brasileira.

PALAVRAS-CHAVE: State action; Constitucionalismo Americano; Direitos Fundamentais.
\end{abstract}

ABSTRACT: The present study intends to clarify the state action doctrine - the fundamental rights protection system applied in the United States of America -, its limits and implications, and, furthermore, to analyze how it is distinguished from the horizontal effect system as adopted by the Brazilian Constitution.

KEYWORDS: State action; American constitutionalism; Fundamental Rights.

SUMÁRIO: 1. Introdução; 2. Sistema Brasileiro da Eficácia Horizontal; 3. Origem do state action; 4. Definição e Extensão do state action; 5. Definição de agente público ("state actor") no sistema americano; 6. Exceções à doutrina do state action; 7. A proteção aos direitos fundamentais nos Estados Unidos; 8. Motivos justificadores para aplicação do state action; 9. Dois importantes casos em que foi aplicado o state action; 10. Conclusão.

\section{INTRODUÇÃO}

Um ordenamento jurídico legítimo é produto da cultura de um dado território. Resulta ele das aspirações do povo subordinado à sua jurisdição, que livremente elege seus representantes com o fim de constituir a legislação que melhor atenda as necessidades de sua pátria.

Por isso, diz-se que um país não deve criticar o sistema jurídico de outro, pois não está sujeito à sua cultura, sua população e sua história, nem experimentou - ou jamais experimentará - os efeitos concretos da influência destas determinantes.

Há certas instituições jurídicas, no entanto, que, de pronto, chocam o jurista alienígena. É o caso do state action. Em poucas palavras, a doutrina do state action

* Advogado da TV Globo. Master of Laws, Universidade de Connecticut. Formado pela Universidade Candido Mendes - Ipanema. O Autor disponibiliza o e-mail para eventuais discussões sobre o tema: odilonb@uol.com.br 
advoga a idéia defendida pela Suprema Corte norte-americana de que nenhuma conduta privada, em tese, é apta a causar uma violação a um direito constitucional.

Somente as relações privadas que já tenham sido objeto de lei ou aquelas nas quais uma das partes esteja agindo como uma longa manus do Estado deverão ser levadas à apreciação do Judiciário.

O state action, aos olhos do jurista de origem romano-germânica, aparece como a perfeita contradição à teoria da eficácia horizontal - hoje adotada na maioria dos Estados Democráticos de Direito, incluindo o Brasil, - uma vez que nega ao Judiciário a competência para resolver litígios envolvendo o abuso a direitos fundamentais quando advindo de relações entre particulares.

Nada obstante, deve-se ressaltar que o state action deve ser examinado à luz do ordenamento jurídico dos Estados Unidos, país sabidamente marcado por forte influência do liberalismo.

A dissertação de fim de curso de LL.M. intitulada "A Comparative Study Between The American And The Brazilian Systems Of Fundamental Rights Protection: Is The State Action Requirement Really Necessary?"1, propôs, como alternativa à doutrina do state action, que os Estados Unidos da América adotassem o sistema da eficácia horizontal, originado da doutrina do magistrado alemão H. C. Nipperdey² . A eficácia horizontal, embora não seja imune a críticas, é amplamente reconhecida como a solução mais justa para a regulação das relações privadas ante o texto constitucional.

O objeto de estudo da mencionada dissertação foi uma comparação entre o sistema americano e o brasileiro de proteção de direitos fundamentais, no qual se concluiu que, afora os problemas de ordem política e econômica encontrados no Brasil, a sua teoria superava, em muito, a americana.

Isto posto, é o objetivo deste artigo esclarecer, em linhas gerais, a doutrina do state action, seus limites e suas implicações, em contraposição ao sistema da eficácia horizontal adotado pela Constituição brasileira.

\section{SISTEMA BRASILEIRO DA EFICÁCIA HORIZONTAL}

Com o fim de poder-se comparar o sistema americano ao brasileiro, cumpre, antes de qualquer coisa, gastar algumas linhas na explicação do chamado sistema da eficácia horizontal.

A aplicação da "eficácia horizontal” da Constituição brasileira resulta primordialmente da aplicação do $\S 1^{\circ}$ de seu art. $5^{\circ}$ que dita que "[a]s normas definidoras dos direitos e garantias fundamentais têm aplicação imediata”.

${ }^{1}$ BORGES NETO, Odilon Castello. A Comparative Study Between The American And The Brazilian Systems Of Fundamental Rights Protection: Is The State Action Requirement Really Necessary?, Puerto Rico Law Review, 2007 (no prelo).

${ }^{2}$ Juan María Bilbao Ubillos (La Eficacia de Los Derechos Fundamentales, Madrid: 1997, Centro de Estudios Políticos y Constitucionales, p. 271) aponta que H. C. Nipperdey rascunhou a idéia no artigo Die Würde des Menschen, publicado como parte da obra coletiva Die Grundrechte. Handbuch Der Theorie Und Praxis DerGrundrechte, organizada por F. L. Neumann, H.C. Nipperdey e V. Shceuner, tomo II, Duncker \& Humblot, Berlim, 1954, p. 18. 
A doutrina de origem alemã prescreve que as normas que tratam sobre direitos e garantias fundamentais não necessitam da salvaguarda do legislador ou do julgador para que produzam efeitos ${ }^{3}$. A rationale é que tais normas, dada sua importância, prescindem da ação legislativa ou judicial, uma vez que a Constituição, trazida para o centro do sistema jurídico, deve guiar toda e qualquer relação jurídica.

Em tempos de neocostitucionalismo e pós-positivismo ${ }^{4}$, já há muito foi explicado pelos juristas pátrios que a Constituição ocupa a posição central do ordenamento jurídico, sendo suas normas dotadas de um efeito irradiante que deverá interferir em todas as esferas do Direito. Portanto, as regras, os princípios e os valores insculpidos na Constituição deverão ser interpretados como peremptórios. É como diz Gustavo Tepedino no artigo "Crise das Fontes Normativas e Técnica Legislativa na Parte Geral do Código Civil de 2002”: "Não há negócio jurídico ou espaço de liberdade privada que não tenha seu conteúdo redesenhado pelo texto constitucional.”

Com o intuito de clarificar como funciona o sistema da eficácia horizontal, é válido ressaltar, em breves linhas, o emblemático julgamento do Recurso Extraordinário $\mathrm{n}^{\circ} 161.243-6 / \mathrm{DF}^{6}$.

Tal questão foi levada ao julgamento do Supremo Tribunal Federal pelo recorrente Joseph Halfin em face da companhia aérea Compagnie Nationale Air France, quando, após ver o seu contrato de trabalho rescindido, reclamou em seu favor determinados benefícios que eram concedidos apenas aos empregados franceses - mesmo no caso daqueles que desempenhavam as mesmas funções dos brasileiros - pelo simples fato de serem franceses.

O Relator Ministro Carlos Velloso valendo-se do parecer da Procuradoria-Geral da República ${ }^{7}$ e das lições de Aristóteles ${ }^{8}$, deu provimento ao pedido do suplicante

\footnotetext{
${ }^{3}$ Muitas linhas já foram gastas no que tange à diferença entre o sistema direto e o indireto de aplicação dos direitos fundamentais às relações entre particulares. No entanto, por não ser este o propósito deste estudo, deve-se estabelecer apenas que grande parte da doutrina entende que existe pouca diferença prática entre os referidos sistemas.

${ }^{4}$ Na explicação do constitucionalista Luís Roberto Barroso (Temas de Direito Constitucional, Tomo III, Rio de Janeiro: Renovar, 2005, p. 508), o "pós-positivismo designa um conjunto difuso e nem sempre sistemático de idéias que se desenvolveram ao longo da segunda metade do século XX” e verificado principalmente após os fenômenos do fascismo italiano e do nazismo alemão. Acrescenta o autor ainda que o "pós-positivismo, sem desprezo à lei, reconhece que o direito não se esgota nos textos legislados", e acaba por promover: “(a) uma reaproximação entre o Direito e a filosofia, entre o Direito e a ética; (b) o reconhecimento de normatividade aos princípios, que são a via pela qual os valores ingressam na ordem jurídica; (c) a centralidade dos direitos fundamentais e as múltiplas implicações daí resultantes”.

${ }^{5}$ Em Revista Forense, v. 364, 2002.

${ }^{6}$ Deparamo-nos pela primeira vez com a mencionada decisão em razão da leitura da obra de Daniel Sarmento (Direitos Fundamentais e Relações Privadas, Lumen Juris: Rio de Janeiro, $2^{a}$ Edição, 2006, p. 250). O autor, citando o julgamento, revela que "na jurisprudência brasileira ocorre um fenômeno de certa forma curioso. Não são tão escassas as decisões judiciais utilizando diretamente os direitos fundamentais para dirimir conflitos de caráter privado. Porém, com raras exceções, estes julgamentos não são precedidos de nenhuma fundamentação teórica que dê lastro à aplicação do preceito constitucional ao litígio entre particulares."

7 O mencionado parecer foi ilustrado com um precedente do próprio STF que regrava que "[a] discriminação proibida é a que se funda em atributo, qualidade, nota intrínseca ou extrínseca do sujeito enunciados na Constituição” (Ag 110.846-1-AgRg-PR, Rel. Min. Célio Borja, in DJ de 5.09.86, p. 15.844) e concluía que o recurso extraordinário comportava tanto conhecimento quanto provimento.

${ }^{8} \mathrm{O}$ Ministro repetiu o famoso adágio de Aristóteles que informa que a prática da igualdade está em tratar igualmente os iguais e desigualmente os desiguais.
} 
para aplicar o texto constitucional em detrimento do regulamento interno da recorrida. Seu posicionamento considerou três determinantes: que o elemento usado para desigualar os trabalhadores - a nacionalidade - seria singularizador do destinatário; que não havia conexão lógica e racional que justificasse o tratamento diferenciado e, por fim, que a diferenciação não apresentava qualquer afinidade com o sistema normativo vigente ${ }^{9}$. Desta forma, entendeu o julgador, não haveria razão para que o princípio constitucional da isonomia, hierarquicamente superior ao regulamento da sociedade, não fosse aplicado ao caso concreto.

Mais recentemente, o Supremo Tribunal Federal, no julgamento do Recurso Extraordinário $n^{\circ}$ 201.819, teve a chance de debater a aplicação da eficácia horizontal, como se vê do trecho da ementa do acórdão ora trazido à colação, reiterando a conclusão expressada pelo Ministro Carlos Velloso na decisão anterior:

Sociedade civil sem fins lucrativos. União brasileira de compositores. Exclusão de sócio sem garantia da ampla defesa e do contraditório. Eficácia dos direitos fundamentais nas relações privadas. Recurso desprovido.

I. Eficácia dos direitos fundamentais nas relações privadas. As violações a direitos fundamentais não ocorrem somente no âmbito das relações entre o cidadão e o Estado, mas igualmente nas relações travadas entre pessoas físicas e jurídicas de direito privado. Assim, os direitos fundamentais assegurados pela Constituição vinculam diretamente não apenas os poderes públicos, estando direcionados também à proteção dos particulares em face dos poderes privados.

II. Os princípios constitucionais como limites à autonomia privada das associações. A ordem jurídico-constitucional brasileira não conferiu a qualquer associação civil a possibilidade de agir à revelia dos princípios inscritos nas leis e, em especial, dos postulados que têm por fundamento direto o próprio texto da Constituição da República, notadamente em tema de proteção às liberdades e garantias fundamentais. O espaço de autonomia privada garantido pela Constituição às associações não está imune à incidência dos princípios constitucionais que asseguram o respeito aos direitos fundamentais de seus associados. (...)

III. (...) As associações privadas que exercem função predominante em determinado âmbito econômico e/ou social, mantendo seus associados em relações

\footnotetext{
${ }^{9}$ Vale colacionar algumas palavras da irrepreensível decisão do Ministro Relator: "É que a "discriminação não pode ser gratuita ou fortuita. Impende que exista uma adequação racional entre o tratamento diferenciado construído e a razão diferencial que lhe serviu de supedâneo”, ou, noutras palavras, "a lei não pode conceder tratamento específico, vantajoso ou desvantajoso, em atenção a traços e circunstâncias peculiarizadoras de uma categoria de indivíduos se não houve adequação racional entre o elemento diferencial e o regime dispensado aos que se inserem na categoria diferenciada. (Celso Antônio Bandeira de Mello, O Conteúdo Jurídico do Princípio da Igualdade, p. 37). (...)

Brasileiros e franceses, empregados da empresa francesa sujeita às leis trabalhistas, não exerciam uns em relação a outros, tarefas diferentes, ontologicamente, mais importantes ou mais difíceis, especiais, uns em relação a outros. Não há, aliás, nos autos, uma só palavra a esse respeito. O fator desigualizador foi, não custa repetir, apenas isto: a nacionalidade. (...)

No caso, porque não ocorrentes os fatores que justificariam o tratamento diferenciado, tem-se que iguais foram tratados desigualmente, o que é ofensivo ao princípio isonômico que a Constituição consagra e que é inerente ao regime democrático e à república.”
} 
de dependência econômica e/ou social, integram o que se pode denominar de espaço público, ainda que não-estatal. A União Brasileira de Compositores-UBC, sociedade civil sem fins lucrativos, integra a estrutura do ECAD e, portanto, assume posição privilegiada para determinar a extensão do gozo e fruição dos direitos autorais de seus associados. A exclusão de sócio do quadro social da UBC, sem qualquer garantia de ampla defesa, do contraditório, ou do devido processo constitucional, onera consideravelmente o recorrido, o qual fica impossibilitado de perceber os direitos autorais relativos à execução de suas obras. A vedação das garantias constitucionais do devido processo legal acaba por restringir a própria liberdade de exercício profissional do sócio. O caráter público da atividade exercida pela sociedade e a dependência do vínculo associativo para o exercício profissional de seus sócios legitimam, no caso concreto, a aplicação direta dos direitos fundamentais concernentes ao devido processo legal, ao contraditório e à ampla defesa (art. 5, LIV e LV, CF/88).

\section{ORIGEM DO STATE ACTION}

Pontuado o sistema nacional da eficácia horizontal, é hora de explorar o direito norte-americano.

O state action é resultado evidente dos ideais liberalistas que acompanharam o nascimento dos Estados Unidos da América. Sua origem remonta às Treze Colônias, quando diversos colonos, a maioria desembarcando da Inglaterra, chegaram ao continente norte-americano com o fim de lá residirem permanentemente e iniciarem a colonização da "Nova Terra".

Da colonização, surgiram diversas colônias, que, embora autônomas umas das outras, de economia auto-suficiente e dotadas de política e cultura próprias, eram ainda dependentes da Inglaterra. Com o desenvolvimento próspero destes territórios, pareceu natural a idéia de se juntarem para formar uma nação maior e mais próspera.

O projeto de união, no entanto, trouxe grande preocupação aos cidadãos das Treze Colônias, uma vez que, apesar da dependência à Inglaterra, tais territórios já eram dotados de vigorosa autonomia. Assim, as primeiras discussões envolvendo a criação de um Estado único foram marcadas pelo medo da dependência a um poder federal dominador.

É importante relembrar, por um lado, que o objetivo das Treze Colônias era justamente a independência. Por outro, os ideais individualistas do liberalismo eram os conceitos dominantes na época. Neste período, o mercantilismo martelava a idéia de que o Estado, para o eficiente controle da economia, deveria, simplesmente, manter-se inerte. Abstendo-se de interferir na economia, o Estado estaria dando aos cidadãos os poderes necessários para que pudessem eficientemente reger suas relações interpessoais. A autonomia privada era o valor maior e o Estado estaria abusivamente interferindo contra ela ao não deixar os cidadãos negociarem por si mesmos, da forma que bem entendessem.

A autonomia privada acarretava, necessariamente, a justiça contratual. Era válido o jargão “diz-se contratual, diz-se justo”. As colônias, então, lutaram para conservar o poder que já possuíam, sem prejuízo de poder gozar das benesses de integrarem uma nação única e autônoma do poder imperial. Tal pressão para que os estados fossem 
dotados de autonomia ficou clara com a adoção do federalismo ${ }^{10}$.

Nesta esteira, é válido notar que a leitura conjugada da Seção 8 do Art. $1^{\text {o }}{ }^{11} \mathrm{com}$ a Décima Emenda ${ }^{12}$ da Constituição norte-americana demonstra porque o governo federal é tido como um órgão dotado de "poderes limitados”"13.

Note-se ainda que a Constituição surgiu como um documento simples e sucinto, com o objetivo de controlar e limitar o poder do ente federal ${ }^{14}$. Com a garantia de não-intrusão estatal e com a liberdade alçada ao posto de mais importante princípio

${ }^{10}$ Federalismo, aqui, na real acepção do termo. Pelas lições de José Afonso da Silva (Curso de Direito Constitucional Positivo, São Paulo: Malheiros Editores, 25 a Edição, p. 99), “[o] federalismo, como expressão do Direito Constitucional, nasceu com a Constituição norte-americana de 1787. Baseia-se na união de coletividades políticas autônomas. Quando se fala em federalismo, em Direito Constitucional, quer-se referir a uma forma de Estado, denominada federação ou Estado federal, caracterizada pela união de coletividades públicas dotadas de autonomia política-constitucional, autonomia federativa”.

${ }^{11}$ Constituição dos Estados Unidos. [No original] Artigo 1. Seção 8. The Congress shall have power to lay and collect taxes, duties, imposts and excises, to pay the debts and provide for the common defense and general welfare of the United States; but all duties, imposts and excises shall be uniform throughout the United States; To borrow money on the credit of the United States; To regulate commerce with foreign nations, and among the several states, and with the Indian tribes; To establish a uniform rule of naturalization, and uniform laws on the subject of bankruptcies throughout the United States; To coin money, regulate the value thereof, and of foreign coin, and fix the standard of weights and measures; To provide for the punishment of counterfeiting the securities and current coin of the United States; To establish post offices and post roads; To promote the progress of science and useful arts, by securing for limited times to authors and inventors the exclusive right to their respective writings and discoveries; To constitute tribunals inferior to the Supreme Court; To define and punish piracies and felonies committed on the high seas, and offenses against the law of nations; To declare war, grant letters of marque and reprisal, and make rules concerning captures on land and water; To raise and support armies, but no appropriation of money to that use shall be for a longer term than two years; To provide and maintain a navy; To make rules for the government and regulation of the land and naval forces; To provide for calling forth the militia to execute the laws of the union, suppress insurrections and repel invasions; To provide for organizing, arming, and disciplining, the militia, and for governing such part of them as may be employed in the service of the United States, reserving to the states respectively, the appointment of the officers, and the authority of training the militia according to the discipline prescribed by Congress; To exercise exclusive legislation in all cases whatsoever, over such District (not exceeding ten miles square) as may, by cession of particular states, and the acceptance of Congress, become the seat of the government of the United States, and to exercise like authority over all places purchased by the consent of the legislature of the state in which the same shall be, for the erection of forts, magazines, arsenals, dockyards, and other needful buildings;--And To make all laws which shall be necessary and proper for carrying into execution the foregoing powers, and all other powers vested by this Constitution in the government of the United States, or in any department or officer thereof.

${ }^{12}$ Constituição dos Estados Unidos. [No original] Emenda X. The powers not delegated to the United States by the Constitution, nor prohibited by it to the States, are reserved to the States respectively, or to the people.

${ }^{13}$ Nesta esteira, deve-se perceber que, na atualidade, e principalmente como resultado dos ataques terroristas de 11 de setembro de 2001, cada vez mais poder é deslocado para o presidente da República. Vide, neste sentido, a perigosa lei editada por George W. Bush denominada Patriot Act e hoje famosa em razão do documentário de longa-metragem "Fahrenheit 9/11" de autoria de Michael Moore.

${ }^{14}$ Não obstante, deve-se ressaltar desde logo que a Constituição dos Estados Unidos possui um artigo que cria restrições não apenas para entes públicos, mas também para particulares, qual seja, a Décima Terceira Emenda, responsável pela proibição da escravidão: “Section 1. Neither slavery nor involuntary servitude, except as a punishment for crime whereof the party shall have been duly convicted, shal exist within the United States, or any place subject to their jurisdiction.” 
do ordenamento jurídico, os indivíduos estariam livres para buscarem seu próprio caminho até a liberdade e a felicidade ${ }^{15}$.

O controle e a regulação das relações entre particulares, incluindo a legislação sobre direitos fundamentais, seguindo a regra geral, ficariam reservados aos entes federados.

À época, vigorava a certeza de que os estados - ainda em número menor a cinqüenta e com população bastante inferior - eram capazes de, por si só, harmonizar os poucos direitos fundamentais que teriam a necessidade de serem especialmente regulamentados, sendo, aliás, capazes de fazê-lo com mais vigor e adequação, pois mais próximos à realidade de seus cidadãos, considerando-se aí principalmente um país que agregava tantas realidades distintas ${ }^{16}$.

O problema é que, o tempo passou, os Estados Unidos se tornaram a maior potência da atualidade, e, apesar do crescente poder gradualmente transferido ao presidente, a doutrina do state action sobrevive pelo julgamento da Suprema Corte e pela insistência da doutrina.

A Suprema Corte enfrentou o assunto de forma mais detida ${ }^{17}$ ao decidir a questão dos Civil Rights Cases $^{18}$, conjunto de casos reunidos para julgamento pela Suprema Corte. Os Civil Rights Cases tinham embasamento na Lei de Direitos Civis de 1875, que garantia a todas as pessoas o livre acesso a locais abertos ao público.

Deve-se, neste passo, frisar que foi com o julgamento destes casos que o state action adquiriu a interpretação rigorosa que o acompanha até os dias de hoje. Assim, apesar de a doutrina classificar o instituto como tendo origem constitucional,

\footnotetext{
${ }^{15}$ A importância que é dada à liberdade pode ser percebida no próprio preâmbulo da Constituição dos Estados Unidos, que aponta como um dos objetivos do texto constitucional "assegurar as Bênçãos da Liberdade": "We the People of the United States, in Order to form a more perfect Union, establish Justice, insure domestic Tranquility, provide for the common defense, promote the general Welfare, and secure the Blessings of Liberty to ourselves and our Posterity, do ordain and establish this Constitution for the United States of America." ${ }^{16}$ Comentando a origem do state action, Chemerinsky (Constitutional Law: Principles and Policies, $2^{\mathrm{a}}$ ed. 2002, p. 456), que é, aliás, um dos poucos doutrinadores americanos a denunciar o mal causado pelo instituto, diz que "isso se deve, em grande parte, ao Federalismo", ou, no original, "[t]his is very much about Federalism".

${ }^{17} \mathrm{E}$ apesar de muitos livros apontarem que a primeira vez que o state action foi analisado pela Suprema Corte foi no julgamento dos Civil Right Cases, a questão, na verdade, foi levada à Suprema Corte pela primeira vez com o julgamento dos Slaughter-House Cases [83 U.S. (16 Wall.) 36 (1873)]. O caso tratava de uma lei do estado da Louisiana que decretou que todo o abate de gado deveria ser realizado por uma determinada companhia, que receberia uma taxa fixa por serviço prestado. A companhia localizava-se em um subúrbio, defendendo o legislador que a rationale da lei seria a saúde da população, que estaria poupada do abate de gado em centros urbanos. Foi, então, proposta uma ação pelos açougueiros daquele estado que se fundamentava, em suma, na idéia de que tal ato restringiria o direito de trabalhar livremente, atentaria contra a cláusula de privilégios e imunidades dos cidadãos e contra o direito de propriedade, sem que lhes fosse garantido o devido processo legal e, por fim, desrespeitaria o princípio da isonomia, embasando sua demanda na Terceira e Quarta Emendas. A Suprema Corte rejeitou o pleito dos açougueiros, sustentando que era da competência dos entes federados decidirem aonde os abates de gado deveriam ocorrer e que as previsões constitucionais não se aplicariam a matérias de interesse privado, que seriam pertinentes apenas à jurisdição do estado editor da lei questionada. Do texto do julgado, no entanto, percebe-se que o entendimento que julgou a decisão dos Justices foi que a Terceira e Quarta Emendas, editadas ao fim da Guerra da Secessão, tinham o exclusivo propósito de protegerem os direitos dos escravos recém-libertados e que jamais poderiam ser aplicadas em outras questões. ${ }^{18} 109$ U.S. 3 (1883).
} 
prefere-se, aqui, tratá-lo como advindo do entendimento jurisprudencial, já que, a nosso ver, o texto constitucional comporta uma interpretação menos maniqueísta ${ }^{19}$.

No julgamento, a lei foi questionada por indivíduos e proprietários de estradasde-ferro que haviam expulsado pessoas negras das instalações de suas propriedades. A maioria dos Justices ${ }^{20}$, ao declararem a lei inconstitucional, deram origem à forma como o state action é visto nos Estados Unidos até os dias de hoje: a Décima Quarta Emenda $^{21}$ ofereceria proteção apenas contra atos de violação a direitos fundamentais cometidos por agentes públicos, mas não contra privações cometidas por particulares.

O Tribunal foi adiante e decidiu que o Congresso, de acordo com a Quinta Seção da Décima Quarta Emenda não poderia legislar sobre condutas particulares, mas apenas regulamentar acerca de ilícitos cometidos por entes públicos. E embora esta visão restritiva dos poderes do Congresso já tenha sido superada, a lógica do state action permanece inalterada ${ }^{22}$ - o Judiciário não pode interferir em condutas meramente privadas, a menos que haja uma lei prevendo a hipótese ou que o agente privado esteja revestido de características de ente público.

Assim, faz-se importante a transcrição do cerne da famosa decisão:

"Direitos civis, tais como são garantidos pela Constituição dos Estados Unidos contra abuso estatal, não podem ser violados por atos ilícitos de indivíduos que não estejam revestidos de autoridade pública. $\mathrm{O}$ ato ilícito de um indivíduo que não esteja agindo revestido desta autoridade é simplesmente um ilícito privado, (...) uma invasão dos direitos da parte lesada, seja ele cometido contra sua personalidade, sua propriedade ou sua reputação. Contudo, caso o abuso não tenha sido objeto de lei ou cometido sob autoridade estatal, seus direitos permaneceriam vigentes e poderiam presumivelmente ser fundamentados em leis estaduais para reparação do dano causado.”

\footnotetext{
${ }^{19}$ Daniel Sarmento, ob. cit., p. 189, p.ex., parece apontar que a doutrina norte-americana entende que o state action tem origem constitucional, como se infere de suas palavras: "Mas é no direito norte-americano que a tese de não-vinculação dos particulares pelos direitos fundamentais estabelecidos em sede constitucional teve a maior difusão. (...) Para justificar esta posição, a doutrina apóia-se na literalidade do texto constitucional, que se refere apenas aos Poderes Públicos na maioria das suas cláusulas consagradoras de direitos fundamentais. Mas também são invocados outros argumentos teóricos, sendo o principal a preocupação com a autonomia privada...”

${ }^{20}$ Justice, segundo o Black's Law Dictionary, é o nome dado a um juiz, especialmente de um tribunal de apelação ou de um tribunal de última instância. Neste artigo, Justice será utilizado para designação dos juízes da Suprema Corte norte-americana.

${ }^{21}$ Constituição dos Estados Unidos. [No original] Emenda XIV. Seção 1. All persons born or naturalized in the United States, and subject to the jurisdiction thereof, are citizens of the United States and of the state wherein they reside. No state shall make or enforce any law which shall abridge the privileges or immunities of citizens of the United States; nor shall any state deprive any person of life, liberty, or property, without due process of law; nor deny to any person within its jurisdiction the equal protection of the laws.

${ }^{22}$ Chemerinsky, cit, p. 487. ("Esta interpretação restritiva do poder do Congresso em face da Décima Terceira Emenda foi rejeitada em casos mais recentes, e atualmente está indubitavelmente estabelecido que o Congresso possui um poder mais amplo sob tal provisão para proibir discriminação racial cometida por particulares. No entanto, recentemente, em United States v. Morrison, a Suprema Corte reafirmou a decisão dos Civil Rights Cases no sentido de que o Congresso não tem o poder, estabelecido na Seção 5 . $^{\mathrm{a}}$ da Décima Quarta Emenda, para regular conduta particular. A decisão principal dos Civil Right Cases (...) permanece como lei e trata-se de princípio do direito constitucional”.)
} 


\section{DEFINIÇÃO E EXTENSÃO DO STATE ACTION}

Assim, de acordo com a interpretação dada pela Suprema Corte ao texto da Décima Quarta Emenda, conclui-se que, em caso de ausência de um ato legislativo estendendo as garantias constitucionais contra abusos decorrentes de relações entre particulares, somente a violação de um direito fundamental cometida por um agente público será sujeita à apreciação pelo Judiciário ${ }^{23}$.

A contrario sensu, caso a mesma perturbação seja cometida por um ente privado, tal direito constitucional não seria merecedor da tutela jurisdicional, restando desamparado.

Portanto, parece-nos fácil concordar com a lúcida opinião de Chemerinsky, que entende que o state action cria um fundamento para que os Tribunais sejam condescendentes com a "violação de quase todo princípio constitucional" ${ }^{24}$. Defendendo a sua abolição, o doutrinador enumera uma série de casos nos quais o requisito foi inegavelmente nocivo contra a proteção da igualdade racial:

Minnick v. California Dep't of Corrections, 452 U.S. 105, 128 (1981) (“Até onde a Constituição vai, uma pessoa privada pode engajar em qualquer discriminação racial que ela queira.”); Save Our Cemeteries, Inc. v. Archdiocese of New Orleans, Inc., 568 F.2d 1074 (5 ${ }^{\circ}$ Circ.) (discriminação por cemitérios particulares não constitui state action), 439 U.S. 836 (1978); Bethel v. Jendoco Constr. Corp., 570 F.2d 1168 ( $3^{\circ}$ Circ. 1978) (discriminação por companhias de construção privadas contra carpinteiros negros não constitui state action); Williams v. Howard Johnson's Restaurant, 268 F.2d 845 (4 Circ. 1959) (discriminação racial por restaurantes particulares não constitui state action); Nicholson v. Quaker Oats. Co., 574 F. Supp. 1209 (D. Tenn. 1983) (discriminação racial por empregador privado não constitui state action); Player $v$. Alabama Dep't of Pensions and Sec., 400 F. Supp. 249 (D. Ala.), decisão mantida, 536 F.2d 1385 (5 ${ }^{\text {th }}$ Cir. 1975) (discriminação racial por creches administradas por autoridade policial não constitui state action); Cook v. Advertiser Co., 323 F. Supp. 1212 (D. Ala. 1971), decisão mantida, 458 F.2d 1119 (5 $5^{\text {th }}$ Cir. 1972) (recusa de um jornal de publicar anúncios de casamentos de pessoas negras não constitui state action) ${ }^{25}$.

Neste ponto, é bom que se esclareça que o reconhecimento de que dada violação tenha sido cometida por um agente estatal não implica declaração imediata de que haja motivo para compensação por dano moral, sendo exatamente aí que reside a principal crítica ao requerimento do state action. Quando o Judiciário reconhece que um alegado ilícito foi cometido por um ente particular, ele está declarando, na verdade, que não tem legitimidade para analisar o mérito do caso, caracterizando-se o state action como uma verdadeira questão anterior ao julgamento do mérito das ações que tenham como objeto abusos contra direitos constitucionais.

\footnotetext{
${ }^{23}$ Richard S. Kay, The State Action Doctrine, The Public-Private Distinction, And The Independence Of Constitutional Law, em Const. Comment., v. 10, pp. 329, 330. ("Mais diretamente relevante é o alcance da doutrina do state action em conexão com certas previsões constitucionais, notadamente com a Cláusula de Isonomia e do Devido Processo Legal da Décima Quarta Emenda. Tem-se entendido que estas previsões aplicam-se apenas aos danos que possam, de alguma forma, serem atribuíveis a um “Estado”.)

${ }^{24}$ Erwin Chemerinsky, Rethinking State Action, em Nw. U. L. Rev., v. 80, 1985, pp. 503 a 509.

${ }^{25}$ Idem.
} 
Por outro lado, é também válido enfatizar que o state action não é uma regra universal que peremptoriamente impede a proteção jurisdicional contra abusos de direitos fundamentais. O Legislativo, ao entender que determinada hipótese é merecedora de tutela, tem legitimidade para criar uma espécie legislativa que seja a ela aplicável. Tal proteção pode ser vista, por exemplo, no direito do trabalho, como aquela dada pela lei federal Labor-Management Relations Act, que garante o direito trabalhista de associação ou de participação em manifestações sindicais.

Com efeito, talvez a legislação mais importante a regular relações privadas é a Civil Rights Act of 1964, editada como resultado dos acalorados movimentos de direitos civis da década de 60 . A lei proíbe a discriminação relacionada a trabalho e educação e garante o idêntico direito de todos de terem acesso a locais públicos.

Já no que tange à regulação dos direitos constitucionais pelos entes federados, vale trazer à baila interessantíssimo estudo do professor da Universidad Pompeu Fabra, Victor Ferreres Comella ${ }^{26}$, apresentado na Faculdade de Direito de Yale:

“Assim, é verdade que a vasta maioria dos estados não tem outorgado proteção à [dimensão privada da] igualdade por meio de suas Constituições. Mas alguns o fazem. Desta forma, a Constituição da Califórnia protege o direito de não ser discriminado no emprego ou no exercício profissional (Artigo 1, Seção 8); a Constituição de Illinois protege este mesmo direito não apenas quanto ao emprego, mas também na venda ou aluguel de propriedades (Artigo 1, Seção 8); a Constituição da Louisiana protege indivíduos contra discriminação em locais públicos (Artigo 1, Seção 12); a Constituição de Montana reconhece o direito universal de não ser discriminado por qualquer pessoa ou empresa privada (Artigo 2, Seção 4); assim como o faz a Constituição de Nova York (Artigo 1, Seção 11) ${ }^{27}$. Ainda que se trate da minoria das Constituições estaduais, estas cláusulas não devem ser menosprezadas, como se fossem completamente estranhas à tradição americana.”

Não obstante estas provisões, deve-se registrar que a proteção legal conferida às relações entre particulares no sistema americano ainda é a exceção, sendo a regra a liberação dos atos discriminatórios cometidos na esfera privada. No geral, a proteção constitucional não alcança "centros não-governamentais de poder”28.

Nesta esteira, ainda é entendimento vigente da própria Suprema Corte que “a ação inibida pela primeira seção da Décima Quarta Emenda da Constituição dos Estados Unidos é apenas aquela ação que pode ser razoavelmente vista como uma ação dos entes públicos. A Décima Quarta Emenda não ergue nenhum escudo contra a ação meramente privada, por mais discriminatória ou ilegal que seja”29.

\footnotetext{
${ }^{26}$ Victor Ferreres Comella. La Eficacia de Los Derechos Constitucionales Frente a Los Particulares, disponível em [http://islandia.law.yale.edu/sela/scomella.pdf\#search=\%22COMELLA\%2C\%20Victor\%20Ferreres.\%20 \%20La\%20Eficacia\%20de\%20Los\%20Derechos\%20Constitucionales\%20Frente\%20a\%20Los\%20Partic ulares\%2C\%20\%22]. Último acesso em 14 de setembro de 2006.

${ }^{27}$ Frise-se, neste ponto, que alguns estados americanos já reconhecem a necessidade de uma regra universal de não-discriminação, o que, em tese, iria de encontro ao requerimento do state action.

${ }^{28}$ Thomas I. Emerson, The First Amendment in the Year 2000, em The Future Of Our Liberties: Perspectives On The Bill Of Rights, Stephen C. Halpern ed., 1982, p. 65.

${ }^{29}$ Shelley v. Kraemer, 334 U.S. 1, 13 (1948).
} 


\section{DEFINIÇÃO DE AGENTE PÚBLICO (“STATE ACTOR”) NO SISTEMA AMERICANO}

Apesar de a tutela jurisdicional ser limitada na proteção dos direitos fundamentais, é indubitável que a Constituição americana se aplica, de forma ampla, às violações de direitos constitucionais cometidas por agentes públicos.

É aí, contudo, que reside uma questão crucial: Até quando um ato cometido por um agente supostamente privado pode ser tido como público?

A própria Suprema Corte admite que a linha que faz tal separação é tênue. Alguns casos são notórios por tentarem traçar tal distinção ${ }^{30}$ e o próprio Tribunal já reconheceu que "apenas peneirando os fatos e pesando as circunstâncias do caso concreto, pode-se atribuir a verdadeira significação do não-óbvio envolvimento do Estado com determinada conduta particular"31.

É importante ressaltar também que esta distinção costuma ser flexibilizada sob determinadas circunstâncias. Assim, em casos de discriminação racial, por exemplo, a Suprema Corte é perceptivelmente menos rígida em restringir um abuso a um direito constitucional por conta do state action ${ }^{32}$.

Não é sem razão que alguns doutrinadores vêem o state action como uma proteção utilizada pelos julgadores para que não discutam questões sérias envolvendo direitos fundamentais. Nesta esteira, já foi dito que "[o] enfoque judicial atual para o state action poderia ser definido como uma "doutrina disfarçada da abstenção": os Tribunais o utilizam para evitar questões fundamentais apresentadas pelos casos concretos”33 $\mathrm{e}$

\footnotetext{
${ }^{30}$ Vide, por exemplo, os casos Evans v. Newton, 382 U.S. 296 (1966) (Senador Bacon, em seu testamento, deixou uma área para ser usada como parque, mas restringiu seu acesso a pessoas brancas. A Suprema Corte, baseada em dois fundamentos - a uma, que parques, diferentemente de clubes, centros sociais e escolas, têm natureza de serviço municipal e, a duas, que operar um parque municipal é função eminentemente pública, não sendo possível delegá-la a particulares -, entendeu que o seu proprietário estaria sujeito à Décima Quarta Emenda e não poderia restringir a entrada ao local.); e Reitman v. Mulkey, 387 U.S. 369 (1967) (Pessoas interessadas em locar apartamentos processaram o eventual locador, Mulkey, quando foram impedidas de fazê-lo pelo simples fato de serem negros. Mulkey, por sua vez, defendeu-se alegando que seu direito era protegido pela Constituição estadual, que trazia um dispositivo proibindo qualquer agência estadual de limitar o direito do locador que preferisse deixar de locar uma propriedade residencial por motivo de foro íntimo. A Suprema Corte, valendo-se da decisão da Suprema Corte da Califórnia, decidiu que qualquer encorajamento estatal de ações privadas configuraria state action. Houve uma opinião divergente defendendo que, para ser inconstitucional, o envolvimento estatal deveria ser comissivo e intencional e que tal distinção seria da competência do Legislativo, mas não do Judiciário.). A nosso ver, ambas as questões são oriundas do direito de propriedade do causador do dano e a aplicação regular do state action ensejaria uma decisão distinta, a qual privilegiaria a autonomia privada do transgressor em detrimento da garantia constitucional da vítima.

${ }^{31}$ Burton v. Wilmington Parking Authority, 365 U.S. 715, 722 (1961).

${ }^{32}$ Erwin Chemerinsky, Rethinking State Action, cit., p. 540. ("Por exemplo, a doutrina do state action é aplicada de forma mais branda em casos envolvendo alegações de discriminação racial por particulares do que em situações em que há violação a outros direitos. Esta perspectiva diferente reflete a conclusão implícita dos tribunais de que impedir a discriminação racial é mais importante do que proteger outros direitos (...). Mas este equilíbrio não é feito de forma explícita pelos tribunais, obscurecido ante a questão da existência ou não do requisito do state action.”).

${ }^{33}$ Anthony Thompson, Piercing the Veil of State Action: The Revisionist Theory and a Mythical Application for Self-Help Repossession, em Wis. L. Rev., v. 1977, 1977, pp. 1-22.
} 
que "[o]s Tribunais estão utilizando este mecanismo como um meio conveniente para evitar assuntos difíceis e delicados quando eles deveriam ser enfrentados”34.

De qualquer forma, embora realmente os limites do state action ainda não estejam bem definidos ${ }^{35}$, existem algumas diretrizes básicas que normalmente são observadas para identificar a sua existência. De acordo com os doutrinadores Rotunda e Nowak ${ }^{36}$, o requerimento do state action apenas surge quando o suposto violador da Constituição esteja agindo por conta própria, sem qualquer envolvimento público. Em geral, o causador do dano defende-se alegando que não é apto a causar uma violação constitucional, por se tratar de um agente privado.

Caberá então ao Judiciário analisar o alcance da conduta praticada pelo agente, se realmente ela se resume à esfera privada ou se atingiu contornos de ato público.

Com efeito, normalmente uma entidade subsidiada pelo governo é considerada ente público ${ }^{37}$, assim como profissionais liberais exercendo cargos públicos ${ }^{38}$.

Sullivan e Gunther ${ }^{39}$ apontam que os casos discutidos sobre o assunto nas últimas cinco décadas apontam relativa ênfase em duas linhas de análise: por um lado, questiona-se se a atividade do agente privado pode ser interpretada como razoavelmente confundida ou "embaraçada" com a do Estado ${ }^{40}$ e, por outro, se a aplicação das garantias constitucionais ao agente privado colide injustamente com a autonomia privada. Aqui, faz-se importante perceber que o Tribunal leva em conta a presunção de que há uma esfera de comportamento privado que realmente deve permanecer livre de qualquer interferência constitucional. Os doutrinadores prosseguem dizendo que os Justices acreditam piamente que a Constituição não deve regular áreas sensíveis à autonomia privada como o direito de associação, direito à privacidade e algumas facetas do direito de propriedade.

Como exemplo, cabe trazer à colação o caso San Francisco Arts \& Athletics, Inc. v. United States Olympic Committee ${ }^{41}$. Neste caso, uma ação foi proposta por uma associação atlética que havia sido impedida de utilizar a palavra "Olimpíada"

\footnotetext{
${ }^{34}$ Jerre S. Williams, The Twilight of State Action, em Tex. L. Rev., v. 41, 1963, pp. 347-382.

${ }^{35}$ Erwin Chemerinsky, Rethinking State Action, cit., p. 503-504. (“Ainda não há princípios claros para determinar se o requisito do state action está ou não presente em dado caso concreto”); Glennon \& Nowak, A Functional Analysis of the Fourteenth Amendment "State Action” Requirement, em Sup. Ct. Rev., V. 1976, p. 221 ("Ainda não existem fórmulas universalmente aceitas para determinar, na prática, qual é a quantidade necessária de ação pública para justificar sua sujeição à restrição governamental.”).

${ }^{36}$ Ronald D. Rotunda \& John E. Nowak, Treatise on Constitutional Law: Substance and Procedure, v. 2, p. 524.

${ }^{37}$ Brentwood Academy v. Tennessee Secondary School, 531 U.S. 288 (2001).

${ }^{38}$ A título de exemplo, os seguintes profissionais foram considerados agentes públicos: um médico chefe do hospital de um presídio (Estelle v. Gamble, 429 U.S. 97 (1976)); médico particular, contratado pelo Estado, que forneceu cuidados médicos na prisão (West v. Atkins, 487 U.S. 42 (1988)). Já o seguinte caso - paradoxalmente - não considerou um defensor público como agente público: o fundamento vencedor foi que sua obrigação de lealdade era voltada para o cliente - não para o governo - e que a relação entre ele e seu cliente não seria diferente de outra relação entre advogado e cliente (Polk Courty v. Dodson, 454 U.S. 312 (1982)).

${ }^{39}$ Kathleen M. Sullivan \& Gerald Gunther, Constitutional Law, 14 Ed., 2001, pp. 870-871.

${ }^{40}$ A Suprema Corte correntemente persegue um “nexo íntimo” entre a conduta particular e a atuação estatal.

${ }^{41} 483$ U.S. 522, 543 (1987).
} 
em suas atividades internas, conhecidas como as “Olimpíadas Gays”. O réu, o Comitê Olímpico dos Estados Unidos (USOC), defendeu-se dizendo que detinha direitos exclusivos sobre a expressão.

Embora o USOC fosse uma entidade parcialmente mantida por subsídios públicos e regulada por lei federal, a Suprema Corte entendeu que o ente público apenas poderia ser responsabilizado por uma decisão de caráter privado caso houvesse exercido pressão de fato para que tal decisão fosse levada a efeito. A mera circunstância de o governo subsidiar uma entidade privada não é capaz de fazê-lo responsável por todos os seus atos e decisões ${ }^{42}$.

Desta forma, facilmente percebe-se que os limites da expressão "state actor" ainda não foram devidamente estabelecidos. Charles Black $\mathrm{Jr}^{43}$, em importante artigo publicado em 1967, já descrevia que os conceitos envolvendo a doutrina do state action eram "desastrosos". Mark Tushnet ${ }^{44}$, citando o artigo, afirma que a situação permanece a mesma desde a publicação dos estudos de Black.

\section{EXCEÇÕES À DOUTRINA DO STATE ACTION}

Existem duas clássicas exceções à doutrina do state action, ambas com o condão de classificar um ente privado como público para permitir que a lide em questão tenha seu mérito apreciado pelo Judiciário.

A primeira é conhecida como “exceção da função pública” e faz-se presente quando uma entidade privada (ou um indivíduo) engaja em uma atividade ou função tradicionalmente desempenhada pelo governo. Sem a aplicação desta exceção, o Estado poderia simplesmente delegar dada função a um ente privado para ficar imune às exigências constitucionais ${ }^{45}$.

No caso Marsh v. Alabama ${ }^{46}$, a Suprema Corte julgou um caso no qual certos cidadãos, proprietários de uma cidade, impediram que Marsh, praticante da religião Testemunhas de Jeová, distribuísse folhetos divulgando o credo nos limites intramunicipais. Por Marsh ter se recusado a sair da cidade, sua prisão, fundamentada numa lei estadual anti-invasão de propriedade, foi decretada. Por tal motivo, ele propôs uma ação argüindo que a lei violara seus direitos garantidos pela Primeira e Décima Quarta Emendas ${ }^{47}$.

\footnotetext{
${ }^{42}$ No presente caso, paira a dúvida se a Suprema Corte aplicou a restrição do state action por se tratar de um caso de discriminação baseado em orientação sexual. Não nos parece provável que o tribunal aplicaria a mesma solução se o caso houvesse sido proposto por uma associação de paraplégicos.

${ }^{43}$ Charles L. Black, Jr., Foreword: State Action, Equal Protection, and California's Proposition 14, $81 \mathrm{em}$ Harv. L. Rev., v. 81, 1967, p. 95.

${ }^{44}$ Mark Tushnet, The Issue of State Action/Horizontal Effect in Comparative Constitutional Law, em ICon 1.1 (79).

${ }^{45}$ Rotunda \& Nowak, Treatise on Constitutional Law, cit., p. 533. ("Se entes privados estão envolvidos no exercício de funções governamentais, suas atividades serão sujeitas às mesmas restrições constitucionais. O Estado não pode se liberar das limitações da Constituição no desempenho de suas funções típicas simplesmente delegando-as a entes privados. Quando agentes particulares assumem o papel do Estado em desempenhar tais funções governamentais, eles estão se auto-sujeitando às mesmas limitações em seu direito de ação que seriam impostas ao próprio Estado. As funções governamentais que são sujeitas a tais restrições são denominadas de “funções públicas”.").

46 326 U.S. 501 (1946).

${ }^{47}$ Direito de livre expressão da religião e garantia do devido processo legal.
} 
O Tribunal deu provimento ao apelo, decidindo que não importava se era um ente público ou particular o responsável pela cidade, pois em ambos os casos “toda a coletividade tem interesse idêntico no funcionamento da comunidade de forma a fazer com que seus canais de comunicação permaneçam livres”48, estabelecendo então o teste da "função pública"49.

A segunda exceção é chamada de “exceção do embaraçamento”. Por ela, uma conduta privada pode ser considerada pública quando o governo, de alguma forma, autoriza, encoraja ou facilita a conduta particular apta a violar um direito constitucional ${ }^{50}$. Chemerinsky aponta que a exceção é geralmente aplicada quando fica demonstrado que o propósito governamental era atentar contra a proteção a direitos constitucionais ou quando o governo esteja facilitando a conduta privada a tal ponto que ela não ocorreria de outra forma.

\section{A PROTEÇÃO AOS DIREITOS FUNDAMENTAIS NOS ESTADOS UNIDOS}

Como explicado, o requerimento do state action é um requisito preliminar à apreciação de casos levados ao Judiciário que tratem de abusos cometidos contra direitos constitucionais. Caso o julgador entenda que o dano foi cometido por um ente privado - que não estava agindo em nome do Estado, nem desempenhando uma função característica de um ente público -, ele não apreciará o mérito da questão, por falta de requisito essencial que lhe permita analisar a matéria.

Na opinião da Suprema Corte dos Estados Unidos, o fato de um amplo leque de violações a direitos fundamentais permanecerem desprovidas de tutela jurisdicional ${ }^{51}$ seria a forma mais eficiente para a preservação de "uma área de liberdade individual",52 e evitaria a responsabilidade do Estado de "regular condutas pelas quais ele não poderia ser razoavelmente culpado" ${ }^{\text {33 }}$. O Tribunal conclui, no texto mesma decisão, que "sendo ou não [o state action] uma boa política, trata-se de um fato fundamental de nosso ordenamento jurídico" 54 .

Com efeito, somente quando o julgador reconhecer a existência do requisito é que o mérito da violação será analisado. Reconhecido o state action, o julgador

\footnotetext{
48326 U.S. 501, p. 507.

${ }^{49}$ A exceção da função pública é bem definida no caso Jackson v. Metropolitan Edison Co., 419 U.S. 345, 352 (1974), no qual a Suprema Corte decidiu que o state action existe "no exercício, por um particular, de poderes que tradicionalmente são exclusivamente reservados ao Estado”. Erwin Chemerinsky, Rethinking State Action, p. 498, acrescenta que "existem três grandes áreas, além daquela apontada no caso Jackson, no qual a Corte tem aplicado a exceção da função pública: na administração de propriedade privada, no controle do processo eleitoral e na gerência e regulação de escolas.”

${ }^{50}$ Lugar v. Edmondson Oil Co. 457 U.S. 922 (1982) (O requerimento de um tribunal e de uma autoridade policial de cobrar uma dívida de caráter particular, dando força a um mandado de arresto, sem que fosse garantido o devido processo legal ao réu, constitui state action); Norwood v. Harrison, 413 U.S. 455 (1973) (O subsídio público concedido a uma escola que discrimina com base na raça viola a cláusula de isonomia da Décima Quarta Emenda e constitui state action).

${ }^{51}$ Em nossa opinião, um direito desprovido da tutela jurisdicional, torna-se um não-direito, haja vista sua ausência de eficácia.

${ }^{52}$ Lugar v. Edmonson Oil Co., 457 U.S. 922, 936 (1982).

${ }^{53}$ Idem, p. 936.

${ }^{54}$ Idem, p. 937.
} 
deverá ponderar, por meio de um rigoroso exame ${ }^{55}$, se a ação realizada pelo agente público era realmente necessária para atingir um interesse governamental convincente. Para demonstrar tal interesse, o agente público arcará com o ônus de provar o nexo de causalidade entre a conduta-fim e a legitimidade de seus meios.

Torna-se importante salientar, neste passo, que os direitos fundamentais usualmente levantados no caso concreto são as cláusulas do devido processo legal da Quinta e Décima Quarta Emendas e a cláusula da isonomia da Décima Quarta Emenda. Este ponto, aliás, é outro objeto de áridas discussões nas cortes americanas. É freqüente a discordância entre os Justices da Suprema Corte sobre qual seria a base constitucional para a proteção de determinado direito fundamental ${ }^{56}$.

Chemerinsky estabelece algumas diretrizes com o fim de analisar o sistema americano de proteção aos direitos fundamentais ${ }^{57}$. Ensina ele que, para que reste configurada uma violação a um direito desta espécie, quatro questões básicas devem ser enfrentadas.

Primeiro, deve-se questionar se o suposto direito alegado pode ser inserido na categoria de direito fundamental. A segunda indagação seria a confirmação de que o direito realmente foi infringido por um ente público. Em seguida, deve-se pesquisar se o agente transgressor tinha um interesse convincente para que desrespeitasse o direito atacado.

Por fim, deveria ser demonstrado que a dita privação seria realmente necessária para atingir o interesse objetivado e que não haveria meios menos restritivos para fazê-lo.

\section{MOTIVOS JUSTIFICADORES PARA APLICAÇÃO DO STATE ACTION}

Toda escolha resulta na necessária exclusão das opções restantes. A postura dos Estados Unidos de supervalorizar a autonomia privada em detrimento da solidariedade é um dos motivos para a sobrevivência do state action.

\footnotetext{
${ }^{55}$ A Suprema Corte deverá, então, aplicar o famoso método do "strict scrutiny" para analisar se os fins almejados pela alegada conduta violadora de um direito fundamental justificariam os meios empregados para tanto.

${ }^{56}$ Vide, neste sentido, a opinião do Justice Stewart em Zablocki v. Redhail, 434. U.S. 378 (1978), caso no qual um cidadão teve o direito de casar novamente recusado na esfera administrativa, pois deixara de pagar alimentos a seus filhos do casamento anterior. Enquanto a maioria dos juízes decidiu que o autor teria razão em seu pleito pois a ele teria sido negada a proteção isonômica das leis, o Justice Stewart entendeu que seria caso de inobservância do devido processo legal. ("Eu não posso concordar com a decisão ora tomada por este Tribunal. Defender, como este Tribunal faz neste caso, que a lei de Wisconsin viola a Cláusula de Isonomia seria aplicar erroneamente o conceito desta garantia constitucional. A Cláusula de Isonomia não lida com direitos materiais ou com liberdades, mas com classificações discriminatórias. O problema neste caso não é de classificação discriminatória, mas de intromissão abusiva sobre uma liberdade protegida constitucionalmente. Eu acredito que a lei de Wisconsin é inconstitucional porque excede os limites permitidos para regulação estadual sobre o casamento e invade a esfera de liberdade protegida pela Cláusula de Devido Processo Legal da Décima Quarta Emenda.”). Confusão similar é vista na opinião divergente do Justice Stone no caso Skinner v. Oklahoma, 316 U.S. 535 (1942) ("Eu concordo com o resultado, mas eu não estou convencido de que nós o atingimos em função da cláusula da isonomia... Eu acredito que o que devemos analisar é se a condenação de uma classe inteira, sem que se dê a oportunidade a um determinado indivíduo de comprovar que o caso específico dele não é aplicável à espécie realmente se trata de uma invasão de liberdade pessoal.)

${ }^{57}$ Erwin Chemerinsky, Constitutional Law, 2001, pp. 698-700.
} 
E não é sem razão que se diz que as idéias liberalistas que fundaram a nação americana ainda hoje influenciam vigorosamente as suas instituições.

Enquanto outras nações ocidentais preferem focar a proteção dada a direitos fundamentais no conceito da dignidade da pessoa humana, os Estados Unidos ainda acreditam que o valor mais importante a ser resguardado é a liberdade. Este é o objeto de estudo da excelente obra de Edward J. Eberle ${ }^{58}$, focada nas diferenças e semelhanças entre os sistemas constitucionais da Alemanha, calcado no princípio da dignidade humana ${ }^{59}$, e dos Estados Unidos, centrado na liberdade. Estes são alguns dos ensinamentos extraídos das idéias do doutrinador:

Enquanto os Estados Unidos e a Alemanha compartilham várias características em suas estruturas constitucionais, tais como a separação de poderes, o federalismo e um Judiciário independente e comprometido com o duplo grau de jurisdição, cada país apresenta uma estratégia constitucional diferente para resguardar a liberdade e a felicidade humana. Os americanos preferem, dentre todos os princípios, dar ênfase à liberdade individual. Para eles, liberdade individual significa liberdade para fazer tudo aquilo que você possa fazer. Do ponto de vista jurídico, esta liberdade significa estar livre de controle oficial ou governamental... A Suprema Corte, através de sua linguagem e de seus julgados, desempenha um importante papel na implementação desta cultura. (...) Os americanos interpretam o conceito de liberdade de forma bastante ampla... Desta forma, ser livre passa a significar fazer tudo que você queira ou goste de fazer. Nesta esteira, liberdade ou autonomia é o objetivo central da ordem jurídica constitucional... Os americanos, portanto, creditam grande valor ao mérito e à habilidade individuais. Acreditam que o indivíduo é quem tem as melhores condições de escolher seus objetivos e, de forma coletiva, o melhor caminho para a sociedade.

\section{(...)}

A Alemanha tem uma estratégia constitucional diferente. Após experimentarem os horrores da época nazista..., os criadores da Constituição construíram um sistema jurídico calcado em princípios ordenados objetivamente e fundamentados na justiça e na igualdade, que dão preferência à ordem social, assegurando, portanto, uma sociedade democrática... No topo desta estrutura de valores está a dignidade humana, que é tida como "inviolável”. Por dignidade humana, os alemães entendem que toda pessoa deve ser tratada como um fim em si mesmo e que a dignidade intrínseca a cada um consiste em perceber e assegurar que todos têm uma personalidade autônoma.

Não se pode olvidar, todavia, que o sistema dos Estados Unidos, tal como é visto hoje, trata-se de uma escolha feita conscientemente pela sociedade americana. A jurisprudência e a doutrina apenas espelham os interesses da nação, refletindo o caráter de produto social que tem o Direito. A atitude individualista e egocêntrica do

${ }^{58}$ Edward J. Eberle, Dignity and Liberty: Constitutional Visions in Germany and the United States, Praeger: 2002, pp. 6-8.

${ }^{59}$ As idéias ora apontadas da Constituição alemã podem ser aplicadas para a realidade da Constituição brasileira, que é muito influenciada por aquela na esfera da proteção aos direitos fundamentais. 
povo americano é característica intrínseca à sua história e fica comprovada, por exemplo, em sua política internacional agressiva ${ }^{60}$ e na orientação excessivamente repressiva de sua justiça ${ }^{61}$.

Tal escolha parece ser diretamente advinda daquela que é apontada como a principal razão para a sobrevivência do state action, qual seja, a intenção de preservar uma esfera de liberdade individual.

E apesar de a Suprema Corte já ter manifestado diversas vezes a importância da defesa do state action para a proteção da liberdade contra a intrusão governamental, vale repetir os sábios ensinamentos de Erwin Chemerinsky. O autor, com o artigo “Rethinking State Action”, escreve aquele que é, a nosso ver, a melhor doutrina hoje encontrada sobre (e contra) o state action.

Nele, o doutrinador aponta que classificar o instituto como desejável é ser simplista, é olhar apenas um lado da equação, porque toda vez que se protege uma violação a um direito constitucional, o direito de outro é sacrificado, causando um dano à liberdade individual desta vítima e protegendo o "arbitrário favoritismo dos opressores sobre os violados" ${ }^{62}$.

Por outra vertente, é interessante ressaltar que a Constituição norte-americana se assemelha ao pensamento que permeou a Revolução Francesa, preferindo, contudo, omitir um dos três valores fundamentais da Época Moderna. A Constituição, apesar de louvar a igualdade e a liberdade, ignorou a fraternidade - valor encampado pelo princípio da solidariedade nas Constituições de grande parte dos Estados Democráticos de Direito.

A provável razão para a exclusão da solidariedade do texto constitucional foi que sua inclusão importaria na necessidade de maior interação entre os entes federados e deles com o poder federal.

\footnotetext{
${ }^{60}$ Recente estudo divulgado por instituições americanas sobre a política internacional dos Estados Unidos comprova que atitudes tais como a barbárie cometida contra prisioneiros de guerra em Abu Ghraib e a manutenção da prisão da Base de Guantánamo, em que os presidiários ficam presos anos a fio sem direito de exercer a garantia do devido processo legal, resultam em um aumento do terrorismo mundial. Neste sentido, é interessante que se registre a opinião do notório escritor e professor aposentado de Massachusetts Institute of Technology Noam Chomsky sobre os Estados Unidos e, em especial, sobre a administração Bush, conforme entrevista publicada no jornal O Globo, p. 42, edição de 15 de outubro de 2006: "Existe um consenso entre os analistas sobre isso [que os EUA são responsáveis pelas sucessivas crises nucleares]. Se você constrói uma enorme capacidade de ofensiva militar e deixa claro que quer atacar qualquer um que esteja indefeso, os adversários em potencial vão reagir. (...) Existem pesquisas feitas pelas mais prestigiadas empresas de pesquisa de opinião [confirmando que os EUA são uma ameaça tão grande à paz quanto Irã e Coréia do Norte]. Segundo eles, mesmo na Europa, onde existe um certo apoio aos EUA, o país é ranqueado como a maior ameaça à paz, é considerado muito mais ameaçador do que a Coréia do Norte e o Irã. (...) Isto aumentou muito nos anos Bush. O presidente conseguiu em alguns anos transformar os EUA no mais temido país do mundo e, freqüentemente, no mais ameaçador.”

${ }^{61}$ É importante apontar, por um lado, que os Estados Unidos possuem uma das maiores taxas de população carcerária do mundo (em geral, a população carcerária americana é de três a oito vezes maior que a população carcerária das nações do ocidente europeu) e, por outro, que o seu sistema de responsabilidade civil conta com o controverso instituto dos punitive damages, que, por vezes, pune o causador de um dano de forma absurdamente excessiva.

${ }^{62}$ Erwin Chemerisnky, Rethinking State Action, cit., pp. 537/540.
} 
A opção pela ausência do princípio da solidariedade e pela supervalorização da liberdade individual traz conseqüências boas e ruins. Se, por um lado, é indiscutível reconhecer que o povo americano é um daqueles que carrega vigoroso senso de cidadania, sendo notório pela louvável atitude de lutar por seus direitos, por outro, implica em uma postura egoística de suas instituições e, conseqüentemente, de seus próprios cidadãos $^{63}$. A preocupação exacerbada com o "meu direito" acaba por ofuscar a necessidade do cumprimento do "meu dever".

Mark Tushnet, enfatizando este ponto de vista, sugere que uma razão para a sobrevivência do instituto é o comprometimento relativamente baixo dos Estados Unidos com as normas social-democráticas, se comparado com outras potências ocidentais ${ }^{64}$.

E o próprio Estado, que, hodiernamente, é visto como “parceiro” do cidadão, o qual, por sua vez, tem o direito de muito exigir dele - seja por meio de uma postura omissiva, seja comissiva ${ }^{65}$ - é tido pela Constituição americana como um "inimigo", como aquele ente capaz de violar direitos e garantias fundamentais ${ }^{66}$.

\footnotetext{
${ }^{63}$ Edward J. Eberle, Dignity and Liberty: Constitutional Visions in Germany and the United States, cit., p. 17. (“A Constituição Americana, como é vista hoje, (...) limita o poder público, mas não educa seus cidadãos ou transmite valores seminais à construção de sua cultura, como é comum no ordenamento jurídico europeu. Neste contexto, a busca individual de liberdade e felicidade se tornou a preocupação primordial, resultando às vezes em individualismo excessivo, resultando às vezes em criativa evolução.”)

${ }^{64}$ Mark Tushnet, The Issue of State Action/Horizontal Effect in Comparative Constitutional Law, cit., p. 50. ("Mas, mesmo os Estados Unidos têm alguns elementos de democracia social nas instituições do estado do bem-estar social criadas nas épocas do New Deal e da Great Society, instituições que permanecem importantes apesar da transformação da política pública dos Estados Unidos desde 1980 e, ainda mais, desde 1994. Luis Michael Seidman e eu temos defendido que o assunto do state action tornou-se urgente nos Estados Unidos precisamente quando o seu governo se tornou comprometido, mesmo que de forma frágil, com as normas social-democratas.”)

${ }^{65}$ Neste passo, enfatize-se que a melhor doutrina aponta que é obrigação constitucional proteger e promover os direitos e interesses da pessoa humana. As palavras do professor Gustavo Tepedino ("Crise de Fontes Normativas e Técnicas Legislativas na Parte Geral do Código Civil de 2002”, em A parte geral do Novo Código Civil: estudos na perspectiva civil-constitucional, Gustavo Tepedino (org.), 2. ed., Renovar: Rio de Janeiro, 2003) resumem de forma brilhante, como lhe é usual, o atual papel da Constituição e a chamada “cláusula de tutela e promoção da pessoa humana”: “...Os preceitos ganham contudo algum significado se interpretados como especificação analítica da cláusula geral de tutela da personalidade prevista no Texto Constitucional nos arts. $1^{\circ}$, III (a dignidade humana como valor fundamental da República), $3^{\circ}$, III (igualdade substancial) e $5^{\circ}, \S 2^{\circ}$ (mecanismo de expressão do rol dos direitos fundamentais). A partir daí, deverá o intérprete romper com a ótica tipificadora seguida pelo Código Civil, ampliando a tutela da pessoa humana não apenas no sentido de admitir uma ampliação de hipóteses de ressarcimento, mas de maneira muito mais ampla, no sentido de promover a tutela da personalidade mesmo fora do rol de direitos subjetivos previstos pelo legislador codificado. (...) Nem parece suficiente o mecanismo simplesmente repressivo e de ressarcimento, próprio do direito penal, de incidência normativa limitada ao aspecto patológico das relações jurídicas, no momento em que ocorre a violação do direito (binômio lesão-sanção), exigindo-se, ao reverso, instrumentos de promoção e emancipação da pessoa, considerada em qualquer situação jurídica que venha a integrar, contratual ou extracontratualmente, quer de direito público quer de direito privado. (...) Com efeito, a escolha da dignidade da pessoa humana como fundamento da República, associada ao objetivo fundamental de erradicação da pobreza e da redução das desigualdades sociais, juntamente com a previsão do $\S 2^{\circ}$ do art. $5^{\circ}$, no sentido de não exclusão de quaisquer direitos e garantias, mesmo que não expressos, desde que decorrentes dos princípios adotados pelo Texto Maior, configuram uma verdadeira cláusula de tutela e promoção da pessoa humana, tornada com valor máximo pelo ordenamento.

${ }^{66}$ Victor Ferreres Comella. La Eficacia de Los Derechos Constitucionales Frente a Los Particulares, cit., p. II-2. ("Em todo Estado liberal, portanto, os direitos são fundamentos e limites do poder estatal.
} 
Com efeito, outras razões são usualmente apontadas para justificar a sobrevivência do state action.

Inicialmente, há outro motivo histórico, qual seja, a proteção ao Federalismo ${ }^{67}$. Quando a Constituição foi escrita, acreditava-se que a common law, por meio das Constituições estaduais, era capaz de resguardar integralmente os direitos fundamentais advindos das relações entre particulares, enquanto o Bill of Rights protegeria os direitos individuais contra a interferência abusiva do poder federal.

À época, havia um único centro de poder forte o suficiente para violar direitos dos cidadãos, qual seja, a União Federal. Todos os cidadãos ocupavam posições sociais equilibradas e não existiam organizações extremamente poderosas, capazes de interferir prejudicialmente nas relações entre particulares.

A clara linha então traçada entre o direito público e o privado impedia a interferência do tratamento dado a um na proteção de direitos contida no outro. O cenário atual, no entanto, comporta uma realidade completamente distinta ${ }^{68}$, em que grandes parcelas de poder foram transferidas para centros não-governamentais de autoridade e no qual novas formas de abuso a direitos fundamentais são percebidas quase que diariamente, sendo que em muitas delas é impossível categorizá-las como sendo de direito público ou privado ${ }^{69}$.

É por tal motivo que Chemerinsky classifica o state action como anacrônico.

Outras causas apontadas para a permanência do instituto é a incerteza jurídica causada por sua abolição e o pretenso engessamento do Judiciário com a possibilidade de grande aumento do volume de ações propostas. Tais fatores, porém, são frágeis por seus próprios fundamentos.

Dito isto, a tradição do Europa continental tem sido mais sensível à idéia do Estado como protetor dos direitos do que a tradição americana. Ainda que ambas as tradições têm reconhecido o caráter ambivalente do Estado (a saber, sua capacidade para atuar, às vezes, como potencial inimigo da liberdade e, às vezes, como amigo dela, para utilizar os termos empregados por Owen Fiss), a concepção européia tem destacado o papel do Estado como protetor de direitos, enquanto a americana tem dado maior ênfase ao seu potencial como agressor.”). Edward J. Eberle, Dignity and Liberty: Constitutional Visions in Germany and the United States, cit., p. 257. (“...Assim, podemos perceber que o objetivo da Lei Alemã é vindicar a dignidade humana. Em comparação, a visão da Constituição americana é mais simples, senão mais superficial. O foco americano é primordialmente delinear os limites do governo, refletindo a revolução republicana americana original e assegurando uma base para a busca pela liberdade e pela felicidade. Os americanos são céticos em relação ao governo. Conseqüentemente, eles confiam mais nas pessoas do que no governo para promover o bem-estar pessoal...”.)

${ }^{67}$ A Suprema Corte acredita que o state action fortalece o Federalismo por preservar uma zona de soberania dos entes federados (Lugar v. Edmonson Oil Co.), 457 US 936.

${ }^{68}$ A nosso ver, o melhor texto retratando o cenário atual é de Michelle Giorgianni (O Direito Privado e as suas Atuais Fronteiras, Revista dos Tribunais, São Paulo, $n^{\circ} 747$, pp. 35-55, jan. 1998), que reporta o hodierno "ofuscamento" entre as fronteiras do direito público e privado.

${ }^{69}$ Barroso (cit., p. 509), tratando sobre o chamado "Novo Constitucionalismo", reitera uma certeza hoje advogada por toda a doutrina mais consciente, qual seja, a atenuação da dualidade público e privado: "Simultaneamente [à passagem da Constituição para o centro do sistema jurídico], verificou-se a perda da centralidade do direito civil, do Código Civil e, no caso de países como o Brasil, dos múltiplos microssistemas que se formaram em torno dele. A própria dualidade extrema entre público e privado, entre direito público e direito privado, foi atenuada, deixou de ser qualitativa e passou a ser quantitativa: a Constituição, o direito público passou a permear as relações jurídicas em geral, em maior ou menor intensidade.” Como conseqüência disto, avança o notável constitucionalista, "passou [a Constituição] a funcionar como a lente, o filtro através do qual se deve olhar para o Direito de uma maneira geral”. 


\section{DOIS IMPORTANTES CASOS EM QUE FOI APLICADO O STATE ACTION}

Todas estas idéias desembocam no state action, um requerimento que tem o propósito de proteger direitos individuais contra a conduta abusiva do Estado, mas que também acaba por promover uma proteção contra a conduta discriminatória por parte de particulares com más intenções.

Um famoso caso que bem espelha a nocividade do instituto é o Moose Lodge No. $107 \mathrm{v}$. Irvis ${ }^{70}$. Moose Lodge era um clube privado cujo regulamento admitia como sócios apenas pessoas brancas, mas que permitia a entrada dos sócios acompanhados de convidados. Uma pessoa negra, Irvis, na condição de convidado, solicitou uma bebida no bar do estabelecimento e teve seu pedido recusado simplesmente por ser negro.

O autor, Irvis, propôs uma ação justificando o state action na licença para vender bebidas alcoólicas concedida pelo estado da Pensilvânia ao clube. Seu pedido restringia-se à revogação da licença estadual enquanto perdurasse aquela política discriminatória e foi fundamentado na cláusula da isonomia da Décima Quarta Emenda.

Apesar de o autor ter seu pedido deferido pelo Tribunal estadual, a Suprema Corte entendeu que a recusa do garçom do clube era lícita, porque o clube era integralmente privado, suas atividades eram todas conduzidas dentro de um estabelecimento particular, ele era subsidiado por um ente privado e apenas a entrada de membros era permitida ${ }^{71}$.

A questão da discriminação racial nem chegou a ser discutida ${ }^{72}$, pois, além de integrar a parte meritória do pleito autoral, a decisão sustentou que "a Corte nunca entendeu, como é óbvio, que a discriminação cometida por uma entidade privada seja apta a violar a Cláusula da Isonomia se a entidade privada não recebe nenhum benefício ou serviço público, ou se não é sujeita, de qualquer forma, à regulação estatal”"73.

É por isso que se diz que, sem o state action, o Judiciário poderia julgar normalmente a ação proposta para analisar se realmente um determinado direito fundamental foi ou não violado.

É importante que se note que em períodos marcados por célebres movimentos sociais, o requerimento do state action foi quase completamente ignorado pela justiça americana. Esta é, aliás, a única explicação plausível para a decisão do famoso caso Shelley v. Kraemer ${ }^{74}$, em que a Suprema Corte declarou que seria ilegal uma cláusula contida em escrituras particulares com fundamento na discriminação racial que a permeava.

O objeto da ação teve origem em 1911, quando donos de propriedades em uma determinada área concordaram que, pelos próximos cinqüenta anos, nenhum deles poderia vender ou locar sua propriedade para pessoas "não-caucasianas". Trinta e quatro anos

\footnotetext{
${ }^{70} 407$ U.S 163 (1972).

${ }^{71}$ Assim foi lavrada a decisão final dos Justices: “A recusa do Moose Lodge de servir comida e bebidas a um convidado em razão do fato de ele ser negro, de acordo com as circunstâncias ora apresentadas, não viola a Décima Quarta Emenda”.

${ }^{72}$ E por mais absurdo que possa soar, a opinião majoritária entendeu que a decisão, de forma alguma, adotaria ou encorajaria a discriminação racial.

${ }^{73} 407$ U.S 163, p. 173.

${ }^{74} 334$ U.S. 1 (1948).
} 
depois, Shelley, um negro, comprou uma propriedade na área, sem que houvesse sido informado da restrição. Em razão desta compra, os outros proprietários brancos da área propuseram uma ação na qual requereram que o título de propriedade fosse revertido a quem vendera o imóvel a Shelley.

A Suprema Corte, analisando o caso, entendeu que, como a Décima Quarta Emenda protege o direito universal de adquirir, usar, gozar e dispor de propriedades imobiliárias, uma lei restringindo a venda de uma propriedade em uma determinada área seria inconstitucional. E mesmo permitindo-se que particulares, em relações estritamente privadas, fossem autorizados a incorrerem em condutas discriminatórias, a participação do Estado não poderia ser tolerada em tais casos.

Questiona-se, aqui, no entanto, onde estaria a participação do ente público, uma vez que nunca foi questionado, nem pelo próprio Judiciário, que a restrição era advinda de uma relação meramente privada.

A Suprema Corte entendeu que a atuação pública na conduta discriminatória surgiria assim que o Estado procedesse à execução de tais contratos, uma vez que os autores apenas poderiam fazer valer seus direitos por meio da tutela jurisdicional. A partir do momento em que o Estado deferisse a demanda proposta, ele estaria negando a garantia constitucional da isonomia a Shelley.

No entanto, deve-se pensar no caso como foi levado ao Judiciário: será que realmente havia uma intervenção pública no ato negocial celebrado entre Shelley e o alienante da propriedade? E na convenção estabelecida entre os demais proprietários, autores da ação?

Analisando friamente o caso, o pleito dos autores se restringia a executar uma cláusula de um contrato - instrumento classicamente classificado como de direito privado - que foi estabelecido entre particulares e que versava sobre o direito mais disponível dentre os chamados direitos disponíveis, a propriedade ${ }^{75}$.

Caso o precedente fosse seguido à risca ${ }^{76}$, o caso Shelley realmente importaria no fim do state action - de fato, ele causou enorme repercussão e foi apontado como o fim do requerimento por grande parte da doutrina. É pensar: se Shelley fosse tido como precedente válido, todo ato discriminatório que fosse levado à análise de um Tribunal estadual e julgado lícito, deveria ser revertido pela Suprema Corte, pois a instância inferior estaria mantendo em vigor uma conduta discriminatória.

No entanto, a Suprema Corte recusou adotar o caso Shelley em oportunidades posteriores, resultando, na visão de Chemerinsky, em um precedente que não pode plausivelmente ser adotado. Assim, considerando o caso ora analisado, pode-se dizer que o state action é um requerimento que não faz muito sentido.

\footnotetext{
${ }^{75}$ Sem desmerecimento da importante função social do contrato e da própria propriedade, é indiscutível que tais questões centram-se na esfera privada de interesses da pessoa humana.

${ }^{76}$ É importante ressaltar, neste ponto, que a controversa decisão foi de 1948, pouco depois da Segunda Guerra Mundial, em que houve um forte movimento por parte da população negra (que formava então grande parte do exército americano enviado à guerra), e no mesmo ano em que o Presidente Harry Truman ordenou o fim da segregação racial nas forças armadas.
} 


\section{CONCLUSÃO}

Desta forma, analisado o instituto do state action, fica demonstrada a sua condição de obstáculo para que o Judiciário americano alcance questões que envolvam abusos a direitos fundamentais. Considerando-se o outro lado da equação, percebe-se também que ele é um instrumento eficaz para atingir algumas das funções para as quais ele foi criado, quais sejam, limitar o papel da Constituição criada para um Estado Federalista e garantir a ampla autonomia privada dos cidadãos.

Fundamentados nesta faceta do state action, cidadãos já tiveram atos aparentemente inconstitucionais declarados como lícitos pela Suprema Corte, em homenagem ao princípio da autonomia privada.

Causa perplexidade, apenas para citar mais um exemplo, a solução judicial conferida ao caso Rendell-Baker v. Kohn ${ }^{77}$. Na ocasião, a decisão de um diretor de uma escola - cujo orçamento era quase integralmente subsidiado pelo Estado, além de o colégio ser regulado por diretrizes públicas - de demitir cinco professores por apoiarem a delegação de maiores responsabilidades ao conselho de estudantes foi deixada de ser julgada pela Suprema Corte, justamente por ausência do requerimento do state action ${ }^{78}$. E não se imagine que o caso é muito antigo ou que já se faz letra morta. A decisão é de 1982 e apesar de já haver sido questionado algumas vezes, ainda se apresenta como precedente válido.

Assim, no caso concreto, se o fundamento do state action era proteger a liberdade individual do diretor da escola, ele cumpriu o seu intento. A questão que deixamos aqui é se este interesse realmente deveria prevalecer sobre um direito constitucional a liberdade de expressão - ou se o interesse social realmente pode ser preterido em razão da vontade individual. É certo que se o caso fosse examinado à luz da eficácia horizontal a preocupação do julgador seria outra, assim como a solução da lide.

Kelsen, ao publicar sua “Teoria Geral do Direito e do Estado”, já dizia que "uma comunidade só será possível se cada indivíduo respeitar certos interesses vida, saúde, liberdade e propriedade - de todos os outros, ou seja, se cada um se abstiver de interferir pela força nas esferas de interesses dos outros”. Desta forma, é de se perguntar: será que a idéia do state action se coaduna com o ideal de um Estado próspero, seja no aspecto democrático quanto no social?

Importante se faz perceber que não está aqui se defendendo que questões relacionadas a direitos fundamentais são facilmente decididas nos sistemas que não adotam o state action. As ações que envolvem o tema sempre se demonstram polêmicas e, por vezes, tendenciosas.

No entanto, não é por isso que o Judiciário deve se furtar a discutí-las, esbarrando em um requerimento que prejudica a análise meritória por si só.

77457 US 830 (1982).

${ }^{78}$ É importante deixar registrada a opinião divergente do Justice Marshall: “A maioria alega que o fato de a escola receber quase todos os seus fundos do Estado não é suficiente, por si só, para justificar a existência do state action. Ela também duvida que o fato de a escola ser intimamente supervisionada e vigorosamente regulada pelo Estado não é suficiente, por si só, para justificar o requisito. Eu geralmente concordo com ambas as premissas. Contudo, quando estes dois fatores estão presentes no mesmo caso e quando outros indícios de state action estão presentes, a existência do requisito pode ser muito bem justificada.” 